\title{
Fibropapillomatosis prevalence and distribution in green turtles Chelonia mydas in Texas (USA)
}

\author{
Donna J. Shaver*, J. Shelby Walker, Thomas F. Backof \\ National Park Service, Padre Island National Seashore, Corpus Christi, TX 78480, USA
}

\begin{abstract}
Fibropapillomatosis (FP) is a neoplastic disease that can result in debilitating tumors in sea turtles. Initially identified in Florida, USA in 1937, it has since been detected in green turtle Chelonia mydas populations globally. FP was first identified and confirmed in Texas, USA in 2010. No FP tumors were documented in Texas prior to that year, though many green turtles were encountered and examined using standardized procedures since 1980. The present study was undertaken to identify temporal and spatial trends of FP prevalence in Texas since 2010. From 2010 through 2018, 1919 stranded or incidentally captured green turtles were documented with FP in Texas. FP prevalence was significantly correlated with year, hypothermic stunning, geographic region, and turtle size, as determined by logistic regression. FP was documented in $<4.0 \%$ of the green turtles examined in Texas from 2010 to 2015 , increasing to $21.6 \%$ in 2016 , $27.3 \%$ in 2017 , and $35.2 \%$ in 2018 . More than twice as many hypothermic stunned green sea turtles had FP tumors as compared to those that were not hypothermic stunned. In Texas, FP was most prevalent in south Texas, particularly in the Laguna Madre, and associated channels. FP was more prevalent in turtles with straight carapace lengths $40.0-69.9 \mathrm{~cm}$. The impact of this disease on green turtle population recovery in Texas is not yet apparent.
\end{abstract}

KEY WORDS: Sea turtles · Green sea turtles · Chelonia mydas · Fibropapillomatosis · Texas

\section{INTRODUCTION}

Fibropapillomatosis (FP) is a disease characterized by tumors of the periocular tissues, skin, carapace, and plastron (Herbst 1994, George 1997), although internal tumors have also been found (Herbst 1994, Work et al. 2004, Foley et al. 2005). Initially identified in green sea turtles in the Florida Keys, USA in turtles captured in 1937 (Smith \& Coates 1938, Hirama \& Ehrhart 2007), FP has since been detected in green sea turtle populations globally (Alfaro-Núñez et al. 2014, Seminoff et al. 2015, Li et al. 2017). FP is considered a threat to some green turtle populations, particularly where there is a high incidence of large tumors that impair vision, movement, or feeding, and thus impact individual survivorship (Ehrhart \& Redfoot 1995).

\footnotetext{
${ }^{*}$ Corresponding author: donna_shaver@nps.gov
}

In the USA, large numbers of green turtles have been afflicted with this disease in Florida (Ehrhart \& Redfoot 1995, Schmid 1998, Hirama \& Ehrhart 1999, 2007, Foley et al. 2005) and Hawaii (Balazs \& Pooley 1991, Balazs et al. 1997, 2000, Work et al. 2015). FP was first confirmed in Texas, USA in 2010 (Tristan et al. 2010). Prior to 2010, no green turtles in Texas were documented with tumors or suspect growths consistent with FP, despite thousands of encounters of green turtles by Sea Turtle Stranding and Salvage Network (STSSN) participants and hundreds of encounters by in-water researchers (Manzella et al. 1990, Coyne 1994, Renaud et al. 1995, Arms 1996, Shaver 2000, Metz \& Landry 2013, Shaver et al. 2013), confirming that the disease was not missed, but was in fact not present prior to 2010 .

(C) Outside the USA, the US Government 2019. Open Access under Creative Commons by Attribution Licence. Use, distribution and reproduction are unrestricted. Authors and original publication must be credited.

Publisher: Inter-Research · www.int-res.com 
The virus associated with FP, chelonid herpesvirus 5 (ChHV5), is believed to have co-evolved with sea turtles for approximately 1 million yr (Herbst et al. 2004), and has genetic variants between populations (Morrison et al. 2018). ChHV5 is found in FP tumors (Herbst 1994, Herbst \& Klein 1995, Quackenbush et al. 1998, Greenblatt et al. 2005, Page-Karjian et al. 2015) and is likely the cause of this disease, though the etiology is not completely understood. There is evidence that turtles acquire the virus after they recruit to a shallow foraging habitat (Ene et al. 2005). Marine leeches, pollution, warm shallow waters, and increasing numbers of green turtles have been implicated in promoting this disease (Greenblatt et al. 2004, Herbst et al. 2004, Foley et al. 2005). Additionally, asymptomatic green turtles can carry the virus, detected as viral DNA in many tissue and fluid types (Page-Karjian et al. 2012, 2015, Alfaro-Núñez et al. 2014, 2016, Chaves et al. 2017).

The present study focuses on quantification of FP tumor cases observed in sea turtles that were documented by the STSSN as stranded (washed ashore or floating, either dead or alive but imperiled) or incidentally captured (entrapped in intake canals of power plants or captured unintentionally while fishing) (Teas 1993) in Texas. Causes of stranding are numerous and include boat strikes, debris entanglement, hypothermic stunning, and disease (Shaver 1998, Shaver et al. 2017). Live stranded turtles are taken to wildlife rehabilitation facilities, while dead turtles are often recovered for investigatory necropsy (Shaver 1998). Our study was undertaken to identify temporal and spatial trends of FP prevalence in Texas since 2010, when the first cases were documented.

\section{MATERIALS AND METHODS}

\subsection{Data collection}

STSSN participants in Texas documented sea turtles found stranded or incidentally captured from 1980 through 2018. For each turtle, information was collected on stranding date, location, tag numbers (if identified), visual signs of disease and/or injuries, condition, and final disposition of the animal. Curved carapace length (nuchal notch to posterior tip; CCL) and straight carapace length (nuchal notch to posterior tip; SCL) were measured for most turtles. Turtles documented with visible tumors characteristic of FP were identified; no attempt was made to quantify asymptomatic turtles via viral DNA in tissues or body fluids. Records were categorized as offshore (from shores or waters of the Gulf of Mexico) or inshore (found on shores or waters of passes and bays). Information was recorded on standardized forms sent to state and national STSSN coordinators. Latitudinal bands were used to divide the Texas coast (Fig. 1) into 3 sections: North, which includes coastal areas in Texas from the Louisiana border at latitude $29.684^{\circ} \mathrm{N}$ through $28.000^{\circ} \mathrm{N}$; Central from $27.999^{\circ} \mathrm{N}$ to $27.000^{\circ} \mathrm{N}$; and South from $26.999^{\circ} \mathrm{N}$ to $25.955^{\circ} \mathrm{N}$, for comparison of FP prevalence. These areas of interest were chosen with respect to variation in geographic features and management.

\subsection{Permitting and animal welfare}

This study was conducted in accordance with the Guide for Care and Use of Laboratory Animals of the National Institutes of Health. Work by National Park Service (NPS) personnel was authorized under US Fish and Wildlife Service Permit TE840727-3, Texas Parks and Wildlife Department Scientific Permit SPR0190-122, and the NPS Institutional Animal Care \& Use Committee permit IMR_PAIS.Shaver.Walker_ SeaTurtle.A3.

\subsection{Data analysis}

The Texas STSSN database was queried for records of green turtles Chelonia mydas documented stranded or incidentally captured in Texas from 1980 to 2018. Stranded and incidentally captured turtles were included in all analyses. FP prevalence analyses were restricted to green turtles documented by the STSSN from 2010 to 2018, years FP was observed in Texas. SCL mean, SD, and range were derived. Turtles were categorized into $10 \mathrm{~cm}$ SCL size classes to illustrate the frequency distribution of FP among these size classes. For 230 turtles, CCL, but not SCL, measurements were obtained, and these were converted for analysis from CCL to SCL using the formula $\mathrm{SCL}=0.294+(0.937 \times \mathrm{CCL})$ (Teas 1993). Turtles described as skeletal or dry carcass were excluded from analysis due to limitations identifying tumors on carcasses in those conditions $(n=1159$; of which only 1 was noted with FP). Repeated measures were also excluded to satisfy model assumptions ( $\mathrm{n}=56$ ). Means are represented with \pm 1 SD.

ArcGIS 10.4.1 (ESRI 2016) was used to display the prevalence and distribution of green turtles with FP tumors encountered between 2010 and 2018 in Texas, USA, displayed as prevalence within $10 \mathrm{~km}$ hexbins. 


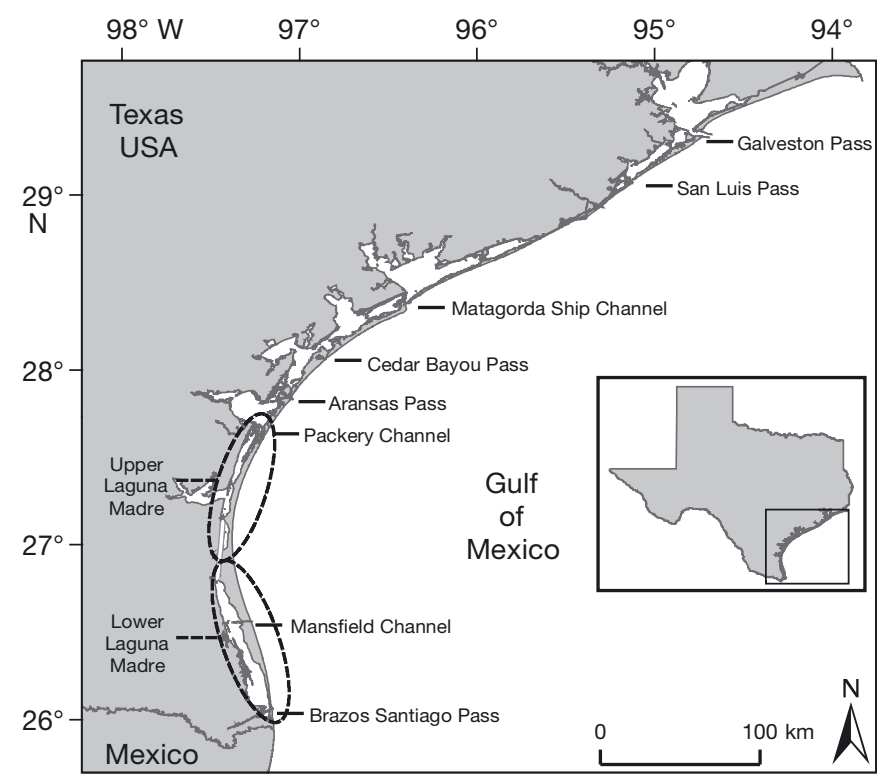

Fig. 1. Texas, USA coast with the locations of major channels and passes as well as the Upper and Lower Laguna Madre (inset: Texas state, with a square around the coastal area)

To determine if FP tumor prevalence varied significantly with the factors coastal region, inshore/ offshore, hypothermic stunned/not hypothermic stunned, stranded/incidental capture, year, and SCL, generalized linear regression models (glm function) were created using R v.3.5.3 (R Core Team 2018). FP was modeled as a binomial (tumor presence, absence) with log transformation, for all factors (full model). Model reduction, i.e. removing insignificant variables, produced a comparable model that did not relay additional information due to the robustness of the relationships in the full model. This insignificance was confirmed using ANOVA and post hoc chi-squared model residuals. Therefore, only the full model is presented. Collinearity was examined for factors Region and SCL, as described in Section 3.

\section{RESULTS}

The generalized linear regression model $(g l m)$ indicated that the variables coastal region and hypothermic stunned/not hypothermic stunned and the covariates year and SCL were all highly significant effects $(\mathrm{p}<0.0001)$ (Table 1). Neither inshore/offshore $(p=0.5870)$ nor incidental capture/ stranded $(p=0.9050)$ were significant
Table 1. Logistic regression analysis of main effects (Year, Hypothermic stunned, Geographic region, and Size class based on straight carapace length) related to prevalence of fibropapilloma tumors (FP) in Chelonia mydas documented in Texas, USA. Estimate: model estimates for $\log$ (odds) at intercept and $\log$ (odds ratios) for each predictor variable; $\mathrm{p}$-values are for Wald test; ${ }^{*}$ significant $(\mathrm{p}<0.05)$

\begin{tabular}{|c|c|c|}
\hline Predictor variable & Estimate & $\mathrm{p}$ \\
\hline Intercept (Central) & -1064.0 & $<0.0001^{*}$ \\
\hline \multicolumn{3}{|l|}{ Region } \\
\hline North & -0.7508 & $<0.0001^{*}$ \\
\hline South & 0.4434 & $<0.0001^{*}$ \\
\hline Inshore/Offshore (Offshore) & -0.0629 & 0.5870 \\
\hline Hypothermic stunned (True) & 0.4912 & $<0.0001^{*}$ \\
\hline $\begin{array}{l}\text { Stranded/Incidentally } \\
\text { captured (Stranded) }\end{array}$ & -0.0253 & 0.9050 \\
\hline Year & 0.5250 & $<0.0001^{*}$ \\
\hline Size class & 0.0803 & $<0.0001^{*}$ \\
\hline \multicolumn{3}{|c|}{$\begin{array}{l}\text { Full model: } \\
\text { FP Region + Inshore/Offshore + Hypothermic stunned } \\
\quad \text { (True/False) + Stranded/Incidentally captured + } \\
\quad \text { Year + Size class; observations }=11050\end{array}$} \\
\hline
\end{tabular}

factors with respect to FP prevalence. FP prevalence increased significantly over the study period $(\mathrm{n}=9$ years, $p<0.0001$ ) (Table 1). A total of 1919 green turtles were detected with FP out of a total of 11360 stranded or incidentally captured green turtles documented in Texas from 2010 to 2018 (16.9\%; Tables 2 \& 3). For the state of Texas, the prevalence of FP did not exceed $5.0 \%$ during any single year from 2010 through 2015, but increased to $21.6 \%$ during 2016, $27.3 \%$ in 2017, and $35.2 \%$ in 2018 (Table 2). More than twice as many hypothermic stunned green turtles were observed with FP tumors $(19.9 \%)$ as compared to turtles that were not hypothermic stunned $(9.4 \%)$ (Table 3$)$.

Table 2. Yearly fibropapillomatosis (FP) prevalence for 3 Texas coastal regions and state totals for Chelonia mydas documented with and without FP. n: number of turtles examined; \%FP: percentage of turtles documented with FP

\begin{tabular}{|c|c|c|c|c|c|c|c|c|}
\hline \multirow[t]{2}{*}{ Year } & \multicolumn{2}{|c|}{ North } & \multicolumn{2}{|c|}{ Central } & \multicolumn{2}{|c|}{ South } & \multicolumn{2}{|c|}{ Total } \\
\hline & $\mathrm{n}$ & $\% F P$ & $\mathrm{n}$ & $\% \mathrm{FP}$ & $\mathrm{n}$ & $\% \mathrm{FP}$ & $\mathrm{n}$ & $\% \mathrm{FP}$ \\
\hline 2010 & 168 & 0.0 & 250 & 0.4 & 293 & 1.0 & 711 & 0.6 \\
\hline 2011 & 108 & 0.0 & 802 & 0.4 & 996 & 7.9 & 1906 & 4.3 \\
\hline 2012 & 51 & 0.0 & 165 & 0.0 & 79 & 2.5 & 295 & 0.7 \\
\hline 2013 & 80 & 0.0 & 438 & 0.7 & 269 & 13.4 & 787 & 5.0 \\
\hline 2014 & 213 & 1.4 & 1026 & 1.3 & 251 & 7.6 & 1490 & 2.3 \\
\hline 2015 & 105 & 2.9 & 613 & 3.1 & 156 & 14.1 & 874 & 5.0 \\
\hline 2016 & 67 & 6.0 & 225 & 21.3 & 116 & 31.0 & 408 & 21.6 \\
\hline 2017 & 120 & 9.2 & 598 & 23.9 & 484 & 30.4 & 1202 & 27.3 \\
\hline 2018 & 494 & 26.1 & 2702 & 37.4 & 491 & 32.2 & 3687 & 35.2 \\
\hline Total & 1406 & 10.7 & 6819 & 18.2 & 3135 & 16.9 & 11360 & 16.9 \\
\hline
\end{tabular}


Table 3. Fibropapilloma tumor (FP) prevalence in Chelonia mydas $(\mathrm{n}=11360)$ documented in Texas, USA, from 2010 to 2018, categorized by those found hypothermic stunned versus those that were not hypothermic stunned, Texas geographic region, and size class (straight carapace length [SCL], $10 \mathrm{~cm}$ bins). Measurements were not obtained for 310 individuals; for 230 individuals, curved carapace length measurements had to be converted to SCL. n: number of turtles examined; \%FP: percentage of turtles documented with FP tumors

\begin{tabular}{|lcc|}
\hline Factor & $\mathrm{n}$ & $\% \mathrm{FP}$ \\
\hline Hypothermic stunned & & \\
$\quad$ True & 7926 & 20.1 \\
False & 3434 & 9.5 \\
Region & & \\
North & 1406 & 10.7 \\
Central & 6819 & 18.2 \\
South & 3135 & 16.9 \\
Size class (cm) & & \\
10.0-19.9 & 85 & 2.4 \\
$20.0-29.9$ & 2385 & 3.1 \\
$30.0-39.9$ & 4773 & 10.3 \\
$40.0-49.9$ & 2334 & 35.5 \\
$50.0-59.9$ & 1069 & 37.6 \\
$60.0-69.9$ & 324 & 29.0 \\
$70.0-79.9$ & 65 & 10.8 \\
$80.0-89.9$ & 13 & 0.0 \\
$90.0-99.9$ & 2 & 0.0 \\
\hline
\end{tabular}

Along the Texas coast, significantly more FP-afflicted turtles have been found in the southern portion of the state, south of Cedar Bayou Pass, which crosses between Mustang Island and Matagorda Island at latitude $28^{\circ} \mathrm{N}$ (Figs. $1 \& 2$ ). This section of the Texas coast is $>250 \mathrm{~km}$ long and has many large bays, including Aransas Bay, Corpus Christi Bay, and the Laguna Madre. For analysis, this section was further divided into a Central region, which includes the Upper Laguna Madre, and South region, which includes the Lower Laguna Madre (Table 2) (see also Section 2.1). FP prevalence differed significantly among these areas ( $\mathrm{n}=3$ regions, $\mathrm{p}<0.0001)$, with the highest prevalence found in the Central area (18.2\%; Tables $2 \& 3)$. FP prevalence was lower and had a slower rate of increase in the North region, from Cedar Bayou Pass northward to the Louisiana border (Tables $2 \& 3$ ). This area of the Texas coast is $>350 \mathrm{~km}$ long and includes Galveston and Matagorda Bays.

SCL of green turtles documented in Texas from 2010 to 2018 ranged from 10.5 to $94.0 \mathrm{~cm}$ (mean: 37.7 $\pm 10.4 \mathrm{~cm}, \mathrm{n}=11050$ ); those recorded with FP ranged from 12.5 to $78.3 \mathrm{~cm} \mathrm{SCL}$ (mean: $44.7 \mathrm{~cm} \pm 9.0 \mathrm{~cm}$, $\mathrm{n}=1901$ ). FP was present in turtles of all $10 \mathrm{~cm}$ size classes except 80.0-89.9 and $90.0-99.9 \mathrm{~cm}$, with the

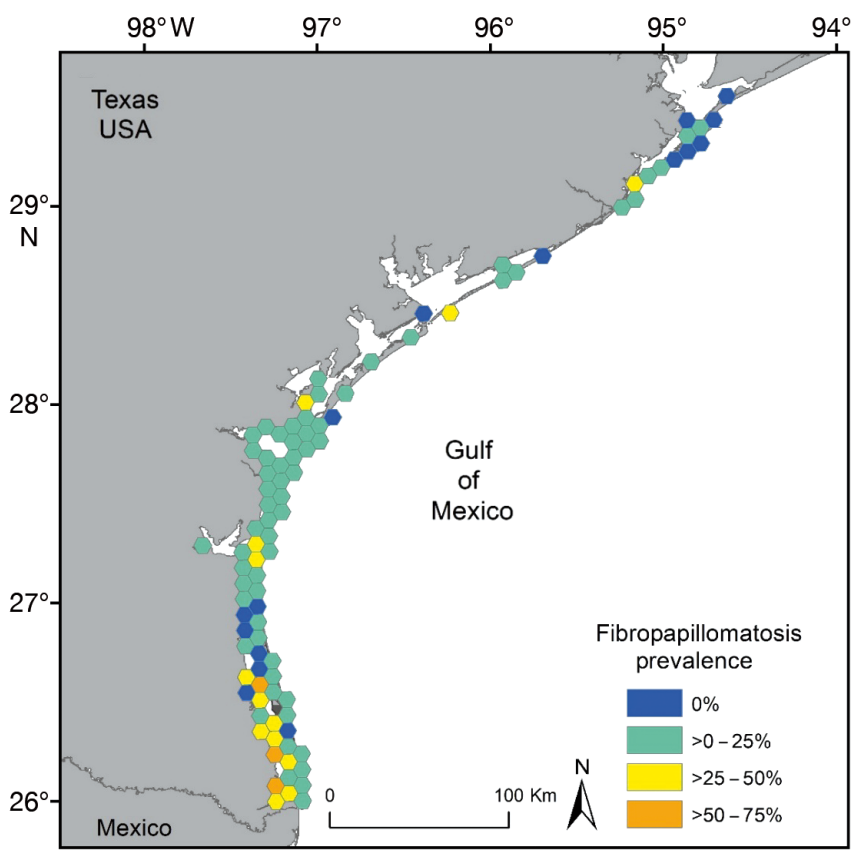

Fig. 2. Distribution and prevalence of green turtles Chelonia mydas documented with fibropapillomatosis (FP) in Texas, USA from 2010 to 2018. Data are percentage of green turtles with FP within $10 \mathrm{~km}$ hexbins, excluding sections with $<10$ encounters

$40.0-49.9$ and $50.0-59.9 \mathrm{~cm}$ size classes having the highest FP prevalence (Table 3).

A pairwise $t$-test indicated that turtles in the South region were significantly larger (mean SCL: $39.6 \pm$ $11.2 \mathrm{~cm} ; \mathrm{n}=3016$ ) than the other 2 regions (both comparisons, $\mathrm{p}<0.0001$; North [mean SCL: $37.1 \pm$ $10.6 \mathrm{~cm}, \mathrm{n}=1372$ ] and Central [mean SCL: $36.9 \pm$ $9.8 \mathrm{~cm}, \mathrm{n}=6612]$, which were not significantly different from each other, $\mathrm{p}=0.45$ ), indicating it was prudent to investigate possible collinearity between the relationship for SCL:Region with FP prevalence by plotting these factors against each other. Collinearity was not observed and was rejected.

\section{DISCUSSION}

The numbers of green turtles documented with FP tumors in Texas has increased at an alarming rate starting in 2015, with higher prevalence in south Texas than north Texas. This trend of increasing tumor prevalence over time was documented in Florida and Hawaii starting in the late 1980s (Foley et al. 2005, Chaloupka et al. 2009). Prevalence of FP varies greatly among other studied areas, though some examined numbers of turtles were captured by netting or other methods. Our inclusion of stranded 
turtles could cause a sampling bias because debilitated turtles, such as those with advanced FP, may be more likely to be found stranded (Foley et al. 2005, Chaloupka et al. 2008, Page-Karjian et al. 2014). However, bias is also possible in netting studies since debilitated turtles may also be more likely to be captured by netting (Limpus et al. 1994). We examined FP prevalence across time and space in Texas, with the source of study animals (stranded and incidentally captured turtles) held constant, limiting bias. Additionally, since $69.8 \%$ of green turtles examined for the present study were hypothermic stunned, capture bias is likely reduced because that stranding cause is likely more indiscriminate, supported by the fact that many otherwise healthy animals are found (Shaver et al. 2017).

High prevalence of FP has been found in other regions of the USA. In fact, high prevalence of FP occurred concurrently during the late 1980s through 1990s in areas of Hawaii and Florida (Balazs et al. 2000, Hirama \& Ehrhart 2007, Chaloupka et al. 2009). However, tumor regression has been noted in many individual green sea turtles in Hawaii, and FP prevalence declined there from $>50 \%$ in the mid-1990s to $9.4 \%$ in 2007, which was similar to levels documented before 1990 (Chaloupka et al. 2009). Prevalence of FP ranged from 4.5 to $7.8 \%$ among different areas for turtles netted in the Key West National Wildlife Refuge (Florida, USA) from 2003 to 2012 (Herren et al. 2018), though it remains as high as $70 \%$ for some lagoons on Florida's Atlantic coast (Ehrhart et al. 2016). FP was present in $13.4 \%$ of netted green turtles in the Turks and Caicos Islands, West Indies (Stringell et al. 2015). Additionally, prevalence of FP fluctuated from 0 to $75 \%$ in netted green turtles at 2 foraging sites in Puerto Rico from 1997 to 2014, with complete regression of visible tumors in individuals occurring within $2.7 \mathrm{yr}$ on average (Patrício et al. 2016). FP tumor presence (31\%, 2008-2010) and regression has been documented in Brazil (Guimarães et al. 2013). In Australia, $7.9 \%$ of green turtles captured in Moreton Bay (1990-1992) had FP tumors (Limpus et al. 1994).

Strong evidence suggests that juvenile green sea turtles are infected by ChHV5 once they reach the inshore neritic foraging habitat (Ene et al. 2005). All individuals detected with FP in our study were juveniles (12.5-78.3 cm SCL) in and near neritic foraging habitat. No nesting green turtles encountered in Texas, to date, have been found with FP tumors, and all have been over $84.0 \mathrm{~cm} \mathrm{SCL}$. Though $18.7 \%$ of green turtles found inshore ( $\mathrm{n}=9138$ examined) had FP tumors, compared to $9.6 \%$ ( $n=2222$ examined) of those found offshore, this difference was not significant. Those found offshore are likely moving there from the inshore areas temporarily, to avoid cold inshore water temperatures during the winter or to migrate to other areas. All Texas bays and estuaries are connected by both oceanic routes and inshore waterways, with the exception of Galveston Bay, which is not connected via the inshore waterway southwest of the $29^{\circ} \mathrm{N}$ latitudinal line, limiting some inshore movement in that area. The lack of intracoastal waterway connection to Galveston Bay may have reduced movement of diseased animals to this area and may be the reason we see a significantly lower prevalence of green turtles with FP north of $29^{\circ} \mathrm{N}$ latitude (North region). Another possible reason that prevalence of FP was lower in the northern portion of Texas is that warmer waters are associated with FP tumor presence and development (Page-Karjian et al. 2014), and water temperatures are on average cooler in the northern part of the state. In Florida, FP prevalence is also more common in the southern portion of the state and very few cases north of $29^{\circ} \mathrm{N}$ latitude have been reported (Schmid 1998, Foley et al. 2005, 2007), strikingly similar to what we report here for Texas.

In Texas, FP tumors were observed most commonly on the ventral surfaces of flippers and on other body surfaces except the carapace. During the study period, no cases of oral FP tumors were recorded in green turtles in Texas. Although oral tumors are rare in Florida (Balazs et al. 1997, 2000), 40-61\% of FPafflicted turtles documented in Hawaii had oral tumors (Balazs et al. 1997, 2000). It is unknown why this disparity exists, but differences in infection route or genetic variants of ChHV5 are implicated (Balazs et al. 1997, 2000). Additionally, internal tumors have been reported in some severe FP cases in the USA (Herbst 1994, Work et al. 2004, Foley et al. 2005), but only 5 cases of internal tumors have been documented to date in green turtles in Texas.

Hypothermic stunning was a significant factor influencing the prevalence of FP tumors documented on turtles in this study. In fact, more than twice as many hypothermic stunned green turtles were observed with FP tumors as compared to turtles that were not hypothermic stunned. The cause of this disparity is not apparent. Further study of the prevalence of FP in green sea turtles in Texas waters is warranted, using a standardized capture method, such as netting.

The fact that FP tumors were first detected in green turtles at neritic foraging areas in southern Florida in 1937 (Hirama \& Ehrhart 2007) and in the Hawaiian 
Islands in 1958 (Balazs \& Pooley 1991), but not in Texas until nearly half a century later, is compelling evidence and could provide clues regarding how the disease spreads to new areas. The Texas neritic foraging juvenile green turtle population is genetically distinct, indicating isolation of these western Gulf of Mexico juvenile green turtles (Shamblin et al. 2017). Thus, the late appearance and increasing prevalence of FP in Texas green turtles could be due to novel incursion of the virus into an immunologically naive population. Increasing FP prevalence is also likely due in part to the concurrent increasing population of Texas juvenile green turtles such that this provides high host density for this infectious disease. It has also been associated with near-shore waters with low water turnover such as lagoons, that contain pollutants, agricultural runoff, or marine biotoxins, and near-shore waters that are adjacent to large human populations (Limpus et al. 1994, Herbst \& Klein 1995, George 1997, Aguirre \& Balazs 2000, Foley et al. 2005, Arthur et al. 2008, dos Santos et al. 2010, Van Houtan et al. 2010, 2014, Patrício et al. 2016). Additionally, if FP prevalence is a reliable method to monitor ecosystem health in near-shore marine habitats as suggested by Aguirre \& Lutz (2004), the health of Texas waters could be in decline.

The green turtle population in Texas, which was decimated by the late 1800 s due to over-harvest and hypothermic stunning (Hildebrand 1983), has been increasing since 2007 (Metz \& Landry 2013, Shaver et al. 2017), just prior to the appearance of FP. FP can cause significant debilitation and even death of individuals. However, it is unknown whether increasing prevalence of FP will slow green turtle population recovery in Texas. FP does not appear to be affecting population demographics for green turtles elsewhere (Foley et al. 2005, Chaloupka et al. 2009, Patrício et al. 2016). It will be vital to monitor FP prevalence over time to identify long-term trends, signs of regression in affected individuals, and possible impacts to the rapidly increasing green turtle population and the health of critical developmental habitat in Texas.

Acknowledgements. We thank M. R. Ellersieck (University of Missouri-Columbia) and C. J. Schmitt (US Geological Survey) for consultation on statistical analyses. We thank Christian Gredzens for preparation of figures and Cameron Purvin for aiding with summary of Texas stranding data. We thank the National Park Service (NPS) employees and volunteers who aided with field activities and coordination, as well as record maintenance for the Sea Turtle Stranding and Salvage Network in Texas. We greatly appreciate many other people and organizations that participated in the network over the decades. Amos Rehabilitation Keep, Coastal
Bend Bays and Estuaries Program, Coastal Conservation Association Hatchery, Florida Fish and Wildlife Conservation Commission, Gladys Porter Zoo, NPS, Naval Air Station Corpus Christi, NOAA-Fisheries, Sea Turtle, Inc., Sea World San Antonio, Texas A\&M University at Corpus Christi, Texas A\&M University at Galveston, Texas General Land Office, Texas Parks and Wildlife Department, Texas Master Naturalists, Texas Sea Grant, Texas Sealife Center, Texas State Aquarium, University of Texas at Pan American, University of Texas Marine Science Institute, US Fish and Wildlife Service, US Geological Survey, US Coast Guard, and other organizations provided assistance, technical support, permitting, and funding for search, rescue, documentation, rehabilitation, and release activities for stranded sea turtles in Texas.

\section{LITERATURE CITED}

Aguirre AA, Balazs GH (2000) Blood biochemistry values of green turtles, Chelonia mydas, with and without fibropapillomatosis. Comp Haematol Int 10:132-137

Aguirre AA, Lutz PL (2004) Marine turtles as sentinels of ecosystem health: Is fibropapillomatosis an indicator? EcoHealth 1:275-283

Alfaro-Núñez A, Bertelsen MF, Bojesen AM, Rasmussen I, Zapeda-Mendoza L, Olsen MT, Gilbert MTP (2014) Global distribution of Chelonid fibropapilloma-associated herpesvirus among clinically healthy sea turtles. BMC Evol Biol 14:206

Alfaro-Núñez A, Bojesen AM, Bertelsen MF, Wales N, Balazs GH, Gilbert MTP (2016) Further evidence of Chelonid herpesevirus 5 (ChHV5) latency: high levels of ChHV5 DNA detected in clinically heathy marine turtles. PeerJ 4:e2274

Arms SA (1996) Overwintering behavior and movement of immature green sea turtles in south Texas waters. MSc thesis, Texas A\&M University, College Station, TX

Arthur KE, Limpus CJ, Wittier JM (2008) Baseline blood biochemistry of Australian green turtles (Chelonia mydas) and effects of exposure to the toxic cyanobacterium Lyngbya majuscula. Aust J Zool 56:23-32

Balazs GH, Pooley SG (1991) Research plan for marine turtle fibropapilloma. NOAA Tech Memo NMFS-SWFSC-156

Balazs GH, Aguirre AA, Murakawa SKK (1997) Occurrence of oral fibropapillomas in the Hawaiian green turtle: differential disease expression. Mar Turtle Newsl 76:1-2

Balazs GH, Murakawa SKK, Ellis DM, Aguirre AA (2000) Manifestation of fibropapillomatosis and rates of growth of green turtles in Kaneohe Bay, Hawaii. In: NOAA Tech Memo NOAA-NMFS-SEFSC-436, p 112-114

Chaloupka M, Work TM, Balazs GH, Murakawa SKK, Morris $\mathrm{R}$ (2008) Cause-specific temporal and spatial trends in green sea turtle strandings in the Hawaiian Archipelago (1982-2003). Mar Biol 154:887-898

Chaloupka M, Balazs GH, Work TM (2009) Rise and fall over 26 years of a marine epizootic in Hawaiian green sea turtles. J Wildl Dis 45:1138-1142

Chaves A, Aguirre AA, Blanco-Peña K, Moreira-Soto A and others (2017) Examining the role of transmission of chelonid alphaherpesvirus 5. EcoHealth 14:530-541

Coyne MS (1994) Feeding ecology of subadult green sea turtles in South Texas waters. MSc thesis, Texas A\&M University, College Station, TX

dos Santos RG, Martins AS, Torezani E, Baptistotte C and others (2010) Relationship between fibropapillomatosis 
and environmental quality: a case study with Chelonia mydas off Brazil. Dis Aquat Org 89:87-95

Ehrhart LM, Redfoot WE (1995) Composition and status of the marine turtle assemblage of the Indian River Lagoon System. Bull Mar Sci 57:279-285

Ehrhart LM, Redfoot W, Mansfield K, Gorham J, Weege S, Provancha J (2016) Prevalence and trends in fibropapillomatosis in green turtles on Florida's Atlantic coast. In: Hargrove S, Work T, Brunson S, Foley AM, Balazs G (eds) Proc 2015 Int Summit Fibropapillomatosis: global status, trends, and population impacts. NOAA Tech Memo NMFS-PIFSC-54, p 15-21

Ene A, Su M, Lemaire S, Rose C and others (2005) Distribution of chelonid fibropapillomatosis-associated herpesvirus variants in Florida: molecular genetic evidence for infection of turtles following recruitment to neritic developmental habitats. J Wildl Dis 41:489-497

ESRI (Environmental Systems Research Institute) (2016) ArcGIS Desktop: release 10.4.1. ESRI, Redlands, CA

Foley AM, Schroeder BA, Redlow AE, Fick-Child KJ, Teas WG (2005) Fibropapillomatosis in stranded green turtles (Chelonia mydas) from the eastern United States (198098): trends and associations with environmental factors. J Wildl Dis 41:29-41

Foley AM, Singel KE, Dutton PH, Summers TM, Redlow AE, Lessman J (2007) Characteristics of a green turtle (Chelonia mydas) assemblage in northwestern Florida determined during a hypothermic stunning event. Gulf Mex Sci 2:131-143

George RH (1997) Health problems and diseases of sea turtles. In: Lutz L, Musick JA (eds) The biology of sea turtles. CRC Press, Boca Raton, FL, p 363-385

Greenblatt RJ, Work TMJ, Balazs GH, Sutton CA, Casey RN, Casey JW (2004) The Ozobranchus leech is a candidate mechanical vector for the fibropapilloma associated turtle herpesvirus found latently infecting skin tumors on Hawaiian green turtles (Chelonia mydas). Virology 321: 101-110

Greenblatt RJ, Quackenbush SL, Casey RN, Rovnak J and others (2005) Genomic variation of the fibropapillomaassociated marine turtle herpesvirus across seven geographic areas and three host species. J Virol 79: 1125-1132

Guimarães SM, Gitirana HM, Wanderley AV, MonteiroNeto C, Lobo-Hajdu G (2013) Evidence of regression of fibropapillomas in juvenile green turtles Chelonia mydas caught in Niterói, southeast Brazil. Dis Aquat Org 102: 243-247

Herbst LH (1994) Fibropapillomatosis of marine turtles. Annu Rev Fish Dis 4:389-425

Herbst LH, Klein PA (1995) Green turtle fibropapillomatosis: challenges to assessing the role of environmental factors. Environ Health Perspect 103:27-30

Herbst LH, Ene A, Su M, Desalle R, Lenz J (2004) Tumor outbreaks in marine turtles are not due to recent herpesvirus mutations. Curr Biol 14:R697-R699

Herren RM, Bagley DA, Bresette MJ, Hollaway-Adkins KG, Clark D, Witherington BE (2018) Sea turtle abundance and demographic measurements in a marine protected area in the Florida Keys, USA. Herpetol Conserv Biol 13: 224-239

Hildebrand HH (1983) Random notes on sea turtles in the Western Gulf of Mexico. In: Owens D, Crowell D, Dienberg G, Grassman M and others (eds) Western Gulf of Mexico Sea Turtle Workshop Proceedings. Publ no.
TAMU-SG-84-105. Texas A\&M Sea Grant College Program, College Station, TX

Hirama S, Ehrhart LM (1999) Prevalence and severity of green turtle fibropapillomatosis in the Indian River Lagoon. Fla Sci 62:35

Hirama S, Ehrhart LM (2007) Description, prevalence and severity of green turtle fibropapillomatosis in three developmental habitats on the east coast of Florida. Fla Sci 70:435-448

Li TH, Hsu WL, Lan YC, Balazs GH, Work TM, Tseng CT, Chang CC (2017) Identification of Chelonid herpesvirus 5 (ChHV5) in endangered green turtles (Chelonia mydas) with fibropapillomatosis in Asia. Bull Mar Sci 93: 1011-1022

Limpus CJ, Couper PJ, Read MA (1994) The green turtle, Chelonia mydas, in Queensland: population structure in a warm temperate feeding area. Mem Queensl Mus 35: 139-154

Manzella SA, Williams JA, Caillouet CW (1990) Radio and sonic tracking of juvenile sea turtles in inshore waters of Louisiana and Texas. In: Richardson TH, Richardson JI, Donnelly M (compilers) Proc 10th Annu Workshop Sea Turtle Biol Conserv. NOAA Tech Memo NMFS-SEFC278, p 115-120

Metz TL, Landry AM (2013) An assessment of green turtle (Chelonia mydas) stocks along the Texas coast, with emphasis on the Lower Laguna Madre. Chelonian Conserv Biol 12:293-302

* Morrison CL, Iwanowicz L, Work TM, Fahsbender E and others (2018) Genomic evolution, recombination, and inter-strain diversity of chelonid alphaherpesvirus 5 from Florida and Hawaii green sea turtles with fibropapillomatosis. PeerJ 6:e4386

* Page-Karjian A, Torres F, Zhang J, Rivera S and others (2012) Presence of chelonid fibropapilloma-associated herpesvirus in tumored and non-tumored green turtles, as detected by polymerase chain reaction, in endemic and non-endemic aggregations, Puerto Rico. SpringerPlus 1: $35-50$

* Page-Karjian A, Norton TM, Krimer P, Groner M, Nelson SE, Gottdenker NL (2014) Factors influencing survivorship of rehabilitating green sea turtles (Chelonia mydas) with fibropapillomatosis. J Zoo Wildl Med 45:507-519

Page-Karjian A, Norton TM, Ritchie B, Brown C, Mancia C, Jackwood M, Gottdenker NL (2015) Quantifying chelonid fibropapilloma-associated herpesvirus in symptomatic and asymptomatic rehabilitating green sea turtles. Endang Species Res 28:135-146

Patrício AR, Diez CE, van Dam RP, Godley BJ (2016) Novel insights into the dynamics of green turtle fibropapillomatosis. Mar Ecol Prog Ser 547:247-255

Quackenbush SL, Work TM, Balazs GH, Casey RN and others (1998) Three closely related herpesviruses are associated with fibropapillomatosis in marine turtles. Virology 246:392-399

R Core Team (2018) R: a language and environment for statistical computing. R Foundation for Statistical Computing, Vienna

Renaud ML, Carpenter JA, Williams JA, Manzella-Tirpak SA (1995) Activities of juvenile green turtles, Chelonia mydas at a jettied pass in south Texas. Fish Bull 93: 586-593

Schmid JR (1998) Marine turtle populations of the westcentral coast of Florida: results of tagging studies at the Cedar Keys, Florida, 1986-1995. Fish Bull 96:589-602 
Seminoff JA, Allen CD, Balazs GH, Dutton PH and others (2015) Status review of the green turtle (Chelonia mydas) under the Endangered Species Act. NOAA Tech Memo NOAA-NMFS-SWFSC-539

Shamblin BM, Dutton PH, Shaver DJ, Bagley DA and others (2017) Mexican origins for the Texas green turtle foraging aggregation: a cautionary tale of incomplete baselines and poor marker resolution. J Exp Mar Biol Ecol 488:111-120

Shaver DJ (1998) Sea turtle strandings along the Texas coast, 1980-94. In: Zimmerman R (ed) Characteristics and causes of Texas marine strandings. NOAA Tech Rep NMFS 143 p 57-72

Shaver DJ (2000) Distribution, residency, and seasonal movements of the green sea turtle, Chelonia mydas (Linnaeus, 1758) in Texas. PhD dissertation, Texas A\&M University, College Station, TX

Shaver DJ, Hart KM, Fujisaki I, Rubio C, Sartain AR (2013) Movement mysteries unveiled: spatial ecology of juvenile green sea turtles. In: Lutterschmidt W (ed) Reptiles in research. Nova Science Publishers, Hauppauge, NY, p 463-483

Shaver DJ, Tissot PE, Streich MM, Walker JS and others (2017) Hypothermic stunning of green sea turtles in a western Gulf of Mexico foraging habitat. PLOS ONE 12: e0173920

Smith GM, Coates CW (1938) Fibroepithelial growths of the

Editorial responsibility: Thierry Work,

Honolulu, Hawaii, USA skin in large marine turtles, Chelonia mydas (Linnaeus). Zool Sci Contrib NY Zool Soc 23:93-98

Stringell TB, Clerveaux WV, Godley BJ, Phillips Q and others (2015) Fisher choice may increase prevalence of green turtle fibropapillomatosis disease. Front Mar Sci 2:57

Teas WG (1993) Species composition and size class distribution of marine turtle strandings on the Gulf of Mexico and southeast United States coast, 1985-1991. NOAA Tech Memo NMFS-SEFSC-315

Tristan T, Shaver DJ, Kimbro J, deMaar T, Metz T, George J, Amos A (2010) Identification of fibropapillomatosis in green sea turtles (Chelonia mydas) on the Texas coast. J Herpetol Med Surg 20:109-112

Van Houtan KS, Hargrove SK, Balazs GH (2010) Land use, macroalgae, and tumor-forming disease in marine turtles. PLOS ONE 5:e12900

*Van Houtan KS, Smith CM, Dailer ML, Kawachi M (2014) Eutrophication and the dietary promotion of sea turtle tumors. PeerJ 2:e602

* Work TM, Balazs GH, Rameyer RA, Morris RA (2004) Retrospective pathology survey of green turtles Chelonia mydas with fibropapillomatosis in the Hawaiian Islands, 1993-2003. Dis Aquat Org 62:163-176

Work TM, Dagenais J, Balazs GH, Schettle N, Ackermann M (2015) Dynamics of virus shedding and in situ confirmation of chelonid herpesvirus 5 in Hawaiian green turtles with fibropapillomatosis. Vet Pathol 52:1195-1201

Submitted: November 19, 2018; Accepted: July 20, 2019

Proofs received from author(s): September 18, 2019 